\section{Australian Journal of \\ Crop Science}

AJCS 15(10):1233-1237 (2021)

doi: 10.21475/ajcs.21.15.10.p2922
ISSN:1835-2707

\title{
Influence of seeding speed and spacing between corn crop lines in the Amazon
}

\author{
Gislayne Farias Valente ${ }^{1 *}$, Vicente Filho Alves Silva ${ }^{2}$, Ricardo Shigueru Okumura ${ }^{2}$, Daiane de Cinque \\ Mariano ${ }^{2}$, José Nilton da Silva ${ }^{2}$, Bruno Borella Anhê ${ }^{3}$, Lana Letícia Barbosa de Carvalho ${ }^{1}$, Danyllo Amaral \\ de Oliveira ${ }^{4}$, Leonardo José Damasceno², Jessivaldo Rodrigues Galvão ${ }^{1}$
}

\author{
${ }^{1}$ Federal Rural University of the Amazon - UFRA, Belém, PA, Brazil \\ ${ }^{2}$ Federal Rural University of the Amazon - UFRA, Parauapebas, PA, Brazil \\ ${ }^{3}$ School of Agriculture "Luiz de Queiroz" - ESALQ/USP, Piracicaba, SP, Brazil \\ ${ }^{4}$ Federal University of Lavras - UFLA, Lavras, MG, Brazil
}

\section{*Corresponding author: Gisllaynnefv@gmail.com}

\begin{abstract}
The sowing stage in the crop implantation process is directly related to its productivity due to factors such as adequacy of the speed of operation of the seeder-fertilizer and the spacing between lines adopted according to each region of Brazil. Thus, the objective of the study was to evaluate the agronomic characteristics of corn in relation to the spacing between rows and speeds of operation of the seeder-fertilizer in the sowing process in the eastern Amazon region. The experiment was carried out in the experimental area of the Technological Center for Support of Family Farming, located in the municipality of Parauapebas, in the southeastern region of Pará. The experimental design used was in continuous bands (subdivided into five plots) of four treatments, resulting in the factorial arrangement $2 \times 2$, consisting of two operating speeds $\left(5.5\right.$ and $\left.6.5 \mathrm{~km} \mathrm{~h}^{-1}\right)$ and two spacings between rows of the seeder-fertilizer $(0.75$ and $0.55 \mathrm{~m})$, totaling 20 experimental plots to evaluate the crop. The evaluations carried out after sowing were: SD (seed depth), TS (total seeds), IP (initial population), PH (plant height), EH (ear height), SD (stem diameter), FP (final population) and SI (survival index). The use of spacing between lines of $0.75 \mathrm{~m}$ promoted an increase in stem diameter $(2.10 \mathrm{~cm})$, plant height $(2.29 \mathrm{~cm})$ and seed depth $(4.97 \mathrm{~cm})$. It was found that the increase in operating speed $(6.5 \mathrm{~km} \mathrm{~h}-1)$ and the use of $0.55 \mathrm{~m}$ line spacing provides an increase in the final plant population $\left(60,000\right.$ plants $\left.\mathrm{ha}^{-1}\right)$.
\end{abstract}

Keywords: germination; mechanized seeding; mechanical seed distributor; seeder-fertilizer; Zea mays L.

Abbreviations: CV\%_coefficient of variation; EH_corn ear height; FP_final population; HP_horsepower; IP_initial population; MSD_minimum significant difference; NPP_nitrogen, phosphorus and potassium; PH_plant height; S_sulfur; Zn_zinc; SD_seed depth; SD_stem diameter; SI_survival index; TS_total seeds.

Introduction

Corn is one of the main cereals produced in the world and the most cultivated in Brazil due to the technological efficiency of management and cultural treatments adopted in the field, ranging from the stage of implantation to the harvest (Farinelli et al., 2012). Among the factors responsible for impacting grain productivity, there is the mechanized sowing operation. At this stage of the process, the tractor-seederfertilizer set is responsible for depositing the seed in the field, being directly related to the uniformity of seed distribution and the development of plants (Cortez et al., 2019). The sowing factors that influence corn production are the sowing speed (Reynaldo et al., 2016), the population arrangement, manipulated through changes in plant density, the spacing between rows and the distribution of plants in the row (Farinelli et al., 2012).

Raises in speed are used to increase the operational capacity of mechanized assemblies (Dias et al., 2014) due to the decrease in the time available for sowing (Mello et al., 2007), which contributes decisively to the longitudinal distribution and mechanical damage of seeds (Silva and Gamero, 2010), compromising seedling germination and emergence.

Inadequate plant spacing also plays an important role in crop productivity, as it is directly related to the efficient use of light, water and nutrients by the plants, which translates into the development and formation of the planting canopy (Hörbe et al., 2016; Piao et al., 2016; Sangoi et al., 2012). The line spacing adopted for the corn crop varies according to each brazilian region in which it is produced, due to the genetic materials of the cultivars that adapt to the intrinsic climatic conditions of each location (Francisco et al., 2017).

According to Sangoi et al. (2011), the new cultivars available on the market are highly sensitive to variations in plant spacing, uniformity and longitudinal distribution, making it necessary to study the implantation of the crop in the field, especially in the edaphoclimatic conditions of the Amazon region. Thus, the objective of the study was to evaluate the agronomic characteristics of corn in relation to the spacing between lines and speeds of operation of the seeder-fertilizer in the sowing process in the Eastern Amazon. 


\section{Results and discussion}

The variables TS, IP, FP, SI and SD presented a coefficient of variation (CV) between 20 and $30 \%$, while the variables SD, $\mathrm{PH}$ and EH obtained values below $10 \%$ (Table 2). According to Gomes and Garcia (2002), the CV indicates the uniformity of the evaluated parameters and are classified as medium (10\% $<\mathrm{CV} \leq 20 \%)$, high $(20 \%<\mathrm{CV} \leq 30 \%)$ and very high ( $\mathrm{CV}>30 \%)$. In a study on the sowing speed in the implantation of corn, Bottega et al. (2014) found a low uniformity in the parameters related to the distribution of seeds in the soil, due to the variation of seed dimensions, the height of fall and the speed of fall in the seed tube in sowing machines.

\section{Spacing between the lines}

From the results obtained, it was found that the spacing between lines influenced the variables, except for the SI and $\mathrm{EH}$ as well as Farinelli et al. (2012) that did not obtain a significant response with the application of line spacing for the variable EH. Gilo et al. (2011) and Takasu et al. (2014), observed significant results for the insertion of the ear for the spacing between lines.

The smallest spacing between lines resulted in the highest TS, IP and FP values with the units of 75.454, 68.636 and 56,363 plants ha-1, respectively (Table 2). While, the values of the variables SD (seed depth), SDI (steam diameter) were higher as the spacing between lines increased, with the values of $4.97,2.10 \mathrm{~cm}$ respectively and $\mathrm{Ph}$ of $2.29 \mathrm{~m}$. Farinelli et al. (2012) evaluated the spacing between lines of $0.40,0.60$ and $0.80 \mathrm{~m}$ for the corn crop in the southeast region of Brazil, and did not obtain a significant response for the variables SD and $\mathrm{EH}$, checking only the $\mathrm{PH}$ with the highest values in the spacing of $0.60 \mathrm{~m}(2.12 \mathrm{~m})$ and $0.80 \mathrm{~m}(2.17 \mathrm{~m})$. In the Cerrado biome, Gilo et al. (2011) evaluating the spacing of 0.45 and $0.90 \mathrm{~m}$, found that the SD had an average value of $1.90 \mathrm{~cm}$ in the smallest spacing and $1.92 \mathrm{~cm}$ in the largest with average plant height of $1.82 \mathrm{~m}$. Kappes et al. (2011) studying the spacing between lines of 0.45 and $0.90 \mathrm{~m}$, observed that the smaller spacing promoted greater SD $(2.01 \mathrm{~cm})$.

In the Northeast region, Porto et al. (2011), who evaluated the performance of corn in the spacing between lines of 0.40 , $0.60,0.80$ and $1.0 \mathrm{~m}$, found that the increase in spacing between lines promoted increases in the height of ear insertion, reaching up to $1.16 \mathrm{~m}$ in $1.0 \mathrm{~m}$ spacing. The same authors also found an increase of $0.49 \mathrm{~m}$ in the height of insertion of the ear for an increase of $0.1 \mathrm{~m}$ in spacing, provided by the interspecific competition of plants. According to Carvalho et al. (2015) the height of plants is directly related to the establishment of crops in the field, and that the lower height of ear insertion contributes to the better balance of the plant, minimizing stem breakage, especially in higher population densities. Corn has a natural tendency to promote higher plant height in situations of high population densities, due to the combined effect of intraspecific competition for light, with a consequent stimulation of apical dominance (Gross et al., 2006; Argenta et al., 2001), since the lower oxidation of auxins stimulates cell elongation and, thus, the internodes of the stem grow longer, increasing the plant's height (Sangoi et al., 2002).

\section{Displacement speed}

From the results obtained for the displacement speed of the seeder-fertilizer, there was a significant effect on the variables TS, IP and SD, in which the speed of $5.5 \mathrm{~km} \cdot \mathrm{h}^{-1}$ promoted a higher average of TS (66.727 seeds ha-1), IP
(60.454 plants ha-1) and SD $(2.04 \mathrm{~cm})$ with average plant height of $2.22 \mathrm{~m}$. Kopper et al. (2017), studying four sowing speeds $\left(5,7,9\right.$ and $\left.11 \mathrm{~km} \mathrm{~h}^{-1}\right)$, found that for the agronomic characteristics of the corn crop, the speed influenced only the height of insertion of the first ear and grain yield. Silva et al. (2000), in a study of speeds of 3, 6, 9 and $11.2 \mathrm{~km} \mathrm{~h}^{-1}$ in the spacing between lines of $0.90 \mathrm{~m}$ using the seed metering mechanism of the horizontal perforated disc type, found that the TS was influenced by speeds from $9 \mathrm{~km} \mathrm{~h}^{-1}$ on reducing the number of plants per linear meter with increasing sowing speed.

The efficiency of the dosing mechanisms is reduced by increasing the speed, since the time to fill the cells of the seed disk is reduced, causing distribution failures (Silva et al., 2000; Bottega et al., 2018). Regardless of the machine and dosing disc used, increasing the speed of operation reduces the number of seeds distributed per unit area (Silva et al., 2000). Bottega et al. (2018) tested three speeds $\left(4,6\right.$ and $8 \mathrm{~km} \mathrm{~h}^{-1}$ ) of displacement of the mechanized set and two seed metering systems (pneumatic and horizontal perforated disc) and observed that the increase in displacement speed in the sowing of corn interfered in the precision and distribution of plants, in which the adequate distribution of plants was obtained at speeds 4 and $6 \mathrm{~km} \mathrm{~h}^{-1}$, using the pneumatic seed doser.

Trogello et al. (2014) studying the spacing between lines of $0.80 \mathrm{~m}$ and operating speeds of 4.5 and $7 \mathrm{~km} \mathrm{~h}^{-1}$, obtained an initial plant population of 71.871 and 70.234 plants ha-1, respectively. The same authors found a relationship between the $\mathrm{PH}$ at the operating speed of 4.5 and $7 \mathrm{~km} \mathrm{~h}^{-1}$ at 35 days after sowing, in which the plants had the higher height of $46.85 \mathrm{~cm}$ at the speed of $4.5 \mathrm{~km} \mathrm{~h}^{-1}$, attributing the result to the initial plant population of 71.871 plants ha-1, $2.3 \%$ higher than that obtained at the speed of $7 \mathrm{~km} \mathrm{~h}^{-1}$.

The IP variable showed a significant difference only between the spacing and speed factors, so, the speed of $5.5 \mathrm{~km} \mathrm{~h}^{-1}$ resulted in a higher IP compared to the speed of $6.5 \mathrm{~km} \mathrm{~h}^{-1}$. Possibly, the increase in the speed of the sowing operation provided greater distance between the seeds, resulting in less amount of seed per linear meter. Storck et al. (2015) found that the machine's travel speed of $7 \mathrm{~km} \mathrm{~h}^{-1}$ determined a greater average of the distance between the plants, reducing the number of plants in the correct spacing between seeds. Boligon et al. (2013) obtained different results in the initial and final population of corn plants, not being influenced by the travel speeds $3.0,4.5$ and $7 \mathrm{~km} \mathrm{~h}^{-1}$.

\section{Interaction between spacing and speed}

From the results of Figure 1, there was an interaction between the spacing and sowing speed for the variable FP, in which the increase in the displacement speed of the tractorseeder set associated with the lower spacing between rows promoted a greater final plant population, which is an important agronomic characteristic in planting because it is directly related to final productivity. Boligon et al. (2013), studying the influence of sowing speed, did not observe significant differences for the final plant population. Silva et al. (2000) and Kopper et al. (2017) found that there was a reduction in the plant population with the increase in travel speed. With the increase in the displacement speed, the rotation speed of the dosing discs proportionally increases, which reduces the time available to fill the holes with seeds, which determines the quality of seed distribution in the furrow and consequently the final plant population (Silva and Gamero, 2010). It is evident that the increase in sowing speed 
Table 1. Chemical characteristics of the soil used in the experiment.

\begin{tabular}{|c|c|c|c|c|c|c|c|c|c|c|}
\hline Depth & $\mathrm{pH}$ & N & MO & P & K & $\mathrm{Na}$ & $\mathrm{Ca}$ & $\mathrm{Ca}+\mathrm{Mg}$ & $\mathrm{Al}$ & $H+A$ \\
\hline $\mathrm{m}$ & $\mathrm{H}_{2} \mathrm{O}$ & $\%$ & $\mathrm{~g} / \mathrm{kg}$ & \multicolumn{4}{|c|}{---------- Mg/dm³ --------- } & \multicolumn{3}{|c|}{----------Cmol/dm³--------- } \\
\hline $0-0.10$ & 5.6 & 0.13 & 13.24 & 2 & 148 & 2 & 4.77 & 6.07 & 0.07 & 1.65 \\
\hline $0.10-0.20$ & 5.6 & 0.14 & 11.51 & 1 & 117 & 4 & 4.83 & 6.22 & 0.06 & 2.15 \\
\hline
\end{tabular}

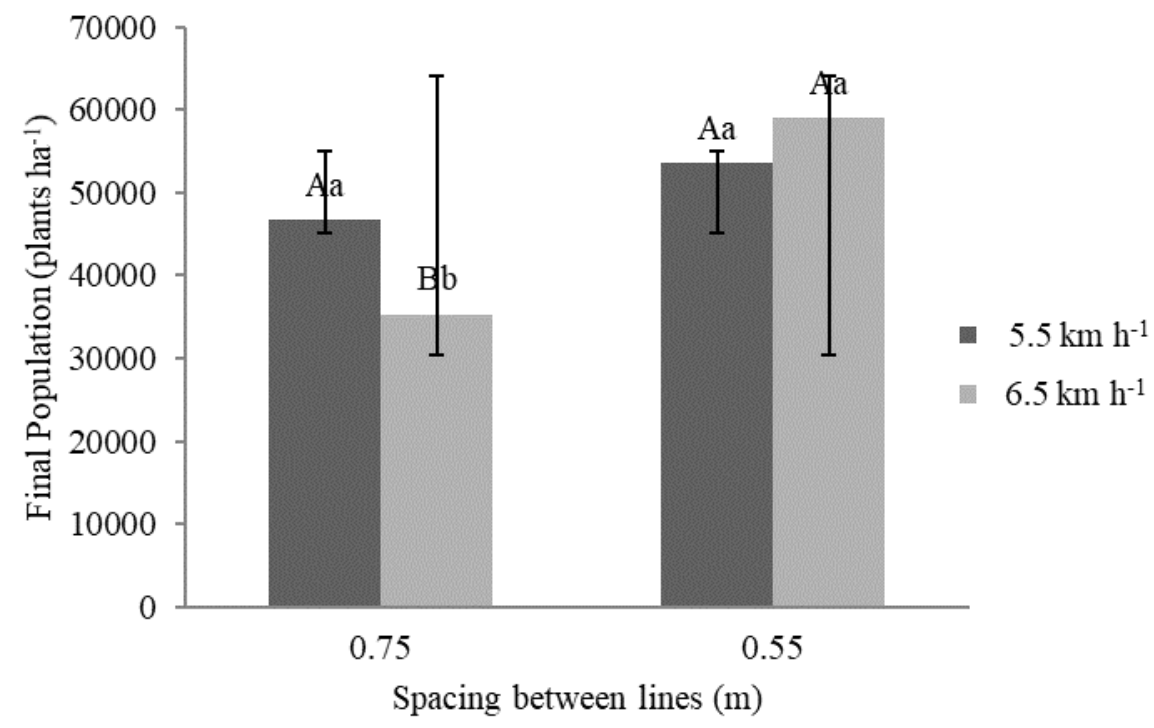

Fig 1. Interaction between sowing speed and spacing for the final population of maize plants.

Table 2. Statistical analysis results of total seeds per area (TS) in seeds $\mathrm{ha}^{-1}$, initial population (IP) and final population (FP) in plants per ha-1, survival index (SI) ear diameter (ED), ear length (EL), plant height (PH), ear height (EH) and stem diameter (SD).

\begin{tabular}{|c|c|c|c|c|c|c|c|c|}
\hline Variables & ST & IP & FP & $\mathrm{SI}$ & SD & DP & $\mathrm{PH}$ & $\mathrm{EH}$ \\
\hline Spacing (E) & & & & $\%$ & \multicolumn{2}{|c|}{------ cm ------ } & \multicolumn{2}{|c|}{------ m ------ } \\
\hline $0.75 \mathrm{~m}$ & $51.333 \mathrm{a}$ & $44.333 \mathrm{a}$ & 40.999 a & $80.53 \mathrm{a}$ & $4.97 \mathrm{a}$ & $2.10 \mathrm{a}$ & $2.29 \mathrm{a}$ & $1.34 \mathrm{a}$ \\
\hline $0.55 \mathrm{~m}$ & $75.454 b$ & $68.636 \mathrm{~b}$ & $56.363 \mathrm{~b}$ & $76.03 \mathrm{a}$ & $4.16 \mathrm{~b}$ & $1.87 \mathrm{~b}$ & $2.18 b$ & $1.35 \mathrm{a}$ \\
\hline \multicolumn{9}{|l|}{ Speed (V) } \\
\hline $5.5 \mathrm{Km}^{-1}$ & $66.727 a$ & $60.454 \mathrm{a}$ & $50.151 \mathrm{a}$ & $76.90 \mathrm{a}$ & $4.56 a$ & $2.04 \mathrm{a}$ & $2.25 \mathrm{a}$ & $1.36 \mathrm{a}$ \\
\hline $6.5 \mathrm{Km}^{-1}$ & $60.060 \mathrm{~b}$ & $52.515 b$ & $47.242 \mathrm{a}$ & 79.65 a & $4.57 \mathrm{a}$ & $1.94 \mathrm{~b}$ & $2.22 \mathrm{a}$ & $1.32 \mathrm{a}$ \\
\hline \multicolumn{9}{|l|}{ F value } \\
\hline $\mathrm{E}$ & $49.1^{* *}$ & $44.92 * *$ & $20.30 * *$ & $0.95^{\text {ns }}$ & $15.4^{* *}$ & $30.5^{* *}$ & $14.91 * *$ & $0.72^{\text {ns }}$ \\
\hline V & $5.24^{*}$ & $3.43^{*}$ & $0.74^{\text {ns }}$ & $0.95^{\text {ns }}$ & $0.00^{\text {ns }}$ & $6.64^{*}$ & $0.71^{\text {ns }}$ & $1.62^{\text {ns }}$ \\
\hline$E \times V$ & $0.95^{\text {ns }}$ & $3.43^{\text {ns }}$ & $6.06^{*}$ & $0.39^{n s}$ & $0.97^{n s}$ & $3.51^{\mathrm{ns}}$ & $2.60^{\text {ns }}$ & $2.66^{\mathrm{ns}}$ \\
\hline DMS & 6.94 & 7.21 & 6.83 & 9.27 & 0.41 & 0.08 & 0.05 & 0.05 \\
\hline CV (\%) & 27.46 & 25.39 & 31.32 & 26.45 & 20.3 & 9.42 & 5.94 & 8.66 \\
\hline
\end{tabular}

* Averages followed by the same lower case letters in the column do not differ, according to the Tukey test, CV: coefficient of variation (\%). ${ }^{* *}$ significant $(\mathrm{P}<0.01){ }^{*}$ significant $(\mathrm{P}<0.05)$. ns: not significant.

contributed to the deposition of the seed in the furrow without compromising the final plant population. As the spacing between lines increased, the author noticed that there was a tendency to increase plant height and stem diameter and despite the tendency to increase plant size, there were no problems related to the lodging or breaking of plants in the area, which leads to greater efficiency in mechanical harvesting and consequently in the final productivity of the corn crop.

\section{Materials and methods}

\section{Experimental Site and Management}

The experiment was carried out from October to March 2014/2015, in the experimental area located in the municipality of Parauapebas, in the southeastern region of Pará, the area's soil was classified as a Dystrophic Red Latosol (Santos et al., 2018), with a geographical location of 49
${ }^{\circ} 51^{\prime} 19^{\prime \prime} \mathrm{W}$ latitude, $06^{\circ} 12^{\prime} 58^{\prime \prime} \mathrm{S}$ longitude and altitude of $197 \mathrm{~m}$. According to the Köppen classification, the municipality of Parauapebas, Pará, has an AW type climate, that is, a tropical rainy season, with concentrated rains in the summer, and a dry season in the winter, which may vary for $\mathrm{Aw}$, with summer and autumn rains of $756.6 \mathrm{~mm}$. During the experiment period, maximum precipitation occurred in December, sowing time, with $246.2 \mathrm{~mm}$. month ${ }^{-1}$ and March with 226, $4 \mathrm{~mm} \mathrm{month}^{-1}$. The history of use in previous years consisted of bean

cultivation and two consecutive corn cultivations under conventional planting. The experimental period covered the 2014/2015 corn cultivation, so the mechanized sowing occurred on October 23 and 24, 2014 using the hybrid Bio Z 236 , with a minimum germination level of $85 \%$ and minimum purity of $98 \%$. The fertilizer used at the time of sowing was NPP: $9-2-15+4 \% \mathrm{~S}+0.4 \% \mathrm{Zn}$, at a dose of $72.5 \mathrm{~kg} \mathrm{ha}^{-1}$. 
The initial soil preparation was carried out using a $4 \times 2$ tractor, with a power of $75 \mathrm{hp}$, with a 7.50-16 tire and the attached Baldan harrow with 14 discs. The first soil preparation took place to incorporate the rest of the previous crop. The second, at the end of August, was carried out for the incorporation of limestone. Subsequently, in October a new harrowing was carried out using the light grid with 22 discs, with the purpose of isolating the area. The mechanical seeder-fertilizer used for conventional planting contained five lines of the brand 2040 Jumil G2, with pantographic coupling frame, rear wheel drive system, double parallel fertilizer disk, double parallel seed disk, with furrow coverers, rear compacting wheel with rubber band, distributor of mechanical seeds with perforated horizontal disc system, fertilizer deposit and seed with a capacity of 39 liters in each. During the experiment, weed control was not carried out.

\section{Experimental design and management}

The experiment was installed in a continuous strip design in four treatments, resulting from the $2 \times 2$ factorial arrangement that consisted of two displacement speeds of the mechanized set $\left(5.5\right.$ and $\left.6.5 \mathrm{~km} \mathrm{~h}^{-1}\right)$ and two spacings between sowing lines $(0.75$ and $0.55 \mathrm{~m})$. Each treatment (strip) contained five sowing lines of $100 \mathrm{~m}$, which were divided into five plots of $20 \mathrm{~m}$ each, totaling 20 plots in the entire area to carry out the evaluations.

\section{Vetegal characteristics}

The variables analyzed were plant height $(\mathrm{PH})$, height of the first ear (EH), stem diameter (SDI), initial population (IP), final population (FP) and survival index (SI), total seeds per area (TS) and seed depth (SD). To evaluate the SD and TS variables, only the first meter of each plot was used, right after the sowing process, where the soil was carefully dug in the central sowing lines in the treatments, up to the place where the seeds were, to measure the depth with the aid of a graduated ruler and quantify the number of seeds. The IP and FP were determined respectively, five days after sowing and in the final data collection, with the help of a measuring tape. An initial meter of the five lines was measured, counting the number of plants and extrapolating the value of plants per ha1. After 75 days of sowing, upon reaching the plant's physiological maturity, the plants were measured with the aid of a measuring tape, to reach the $\mathrm{PH}, \mathrm{EH}$ and SD values.

\section{Measuring the survival rate}

The SD was measured above the third internode with the aid of a digital caliper. To determine the SI, the average proportion of plants that reached maturity was calculated in relation to the initial average plant population, represented by equation 1 .

In

which:

\section{(Eq.1)}

$S I=\frac{F P}{I P l} \times 100$

SI: Survival Index (\%);

FP: Final Plant Population (plants.ha-1);

IP: Initial Plant Population (plants.ha-1).

\section{Statistical analyses}

The experimental data was subjected to the Shapiro-Wilk and Levene tests at $1 \%$ probability, to verify residual normality and homoscedasticity. After meeting the basic assumptions, the analysis of variance was performed and the Tukey test was applied, at $5 \%$ probability, to compare the treatment means, using the SISVAR statistical software (Ferreira, 2019).

\section{Conclusion}

The use of the mechanized set with greater distance between sowing lines $(0.75 \mathrm{~m})$ resulted in an adequate seed depth for the establishment of the crop and favorable agronomic characteristics of plants, such as the increases in stem diameter and height of the plants.

The combination of the speed of $6.5 \mathrm{~km} \mathrm{~h}^{-1}$ with the line spacing of $0.55 \mathrm{~m}$ promotes the largest final plant population (60.000 plants ha- 1 ) in the edaphoclimatic conditions of the eastern Amazon.

\section{References}

Argenta G, Silva PRF, Sangoi L (2001) Arranjo de plantas em milho: análise do estado-da-arte. Cienc Rural. 31:10751084.

Boligon F, Helena L, Nobrega P, Souza EG, Pacheco FP, Silveira JCM (2013) Aspectos relacionados à densidade populacional de plantas de milho em função da velocidade de deslocamento e do mecanismo dosador de sementes em duas semeadoras adubadoras. Rev Varia Sci Agrar. 03:8194.

Bottega EL, Rosolem DH, Oliveira Neto AM, Piazzetta HVL, Guerra N (2014) Qualidade da semeadura do milho em função do sistema dosador de sementes e velocidades de operação. Global Sci Technol. 07:107-114.

Bottega EL, Vian T, Guerra N, Oliveira Neto AM (2018) Diferentes dosadores de sementes e velocidades de deslocamento na semeadura do milho em plantio direto. Pesqui Agropecu Bras. 22:201-707.

Carvalho IDE, Ferreira PV, Silva JP, Costa KDS, Oliveira FS (2015) Comportamento produtivo de genótipos de milho (Zea mays L.) em diferentes espaçamentos sob adubação orgânica. Agropecuária Científica no semi-árido. 11:97107.

Cortez JW, Armando E J, Motomiya AVA, Rodrigues AS, Gonçalves EA (2019) Soil physical attributes before and after management under sowing forward speed. Eng AgrJaboticabal. 39:607-615.

Dias VO, Alonço AS, Carpes DP, Veit AA, Souza LB (2014) Velocidade periférica do disco em mecanismos dosadores de sementes de milho e soja. Cienc Rural. 44:1973-1979.

Santos HG et al (2018) National Center of Soil Research Brazilian System of Soil Classification. Embrapa, press, Brasília. 5:353.

Farinelli L, Penariol FG, Fornasieri DF (2012) Características agronômicas e produtividade de cultivares de milho em diferentes espaçamentos entre linhas e densidades populacionais. Científica. 40:21-27.

Ferreira DF (2019) Sisvar: A computer analysis system to fixed effects split plot type designs. Rev Bras Biometria. 37:529535.

Francisco PRM, Santos D, Guimarães CL, Araujo SRD, Oliveira FP (2017) Aptidão climática do milho (zea mays I.) para o estado da paraíba. Rev Geogr. 34:209-301.

Gilo EG, Silva Junior CA, Torres FE, Nascimento ES, Lourenção AS (2011) Comportamento de híbridos de milho no cerrado sul-matogrossense, sob diferentes espaçamentos entre linhas. Biosci J. 27:908-914.

Gomes FP, Garcia CH (2002) Estatística aplicada a experimentos agronômicos e florestais: exposição com 
exemplos e orientações para uso de aplicativos, $1^{\circ} \mathrm{edn}$. Piracicaba, Brasil.

Gross MR, Pinho RGV, Brito AH (2006) Adubação nitrogenada, densidade de semeadura e espaçamento de fileiras na cultura do milho em sistema plantio direto. Cienc Agrotec. 30:387-393.

Hörbe TAN, Amado TJC, Reimche GB, Schwalbert RA, Santi AL, Nienow C (2016) Optimization of within-row plant spacing increases nutritional status and corn yield: A comparative study. Agron J. 108:1962-1971.

Kappes C, Andrade JAC, Arf O, Oliveira AC, Arf MV, Ferreira JP (2011) Desempenho de híbridos de milho em diferentes arranjos espaciais de plantas. Bragantia.70:334-343.

Kopper CV, Meert L, Krenski A, Borghi WA, Oliveira Neto AM, Figueiredo AST (2017) Produtividade de milho segunda safra em função de diferentes velocidades de semeadura e densidade de plantas. Pesqui Agropecu Pernamb. 22:201701.

Mello AJR, Furlani CEA, Silva RP, Lopes A, Borsatto EA (2007) Produtividade de híbridos de milho em função da velocidade de semeadura. Eng Agr-Jaboticabal. 27:479486.

Piao L, Qi H, Li C, Zhao M (2016) Optimized tillage practices and row spacing to improve grain yield and matter transport efficiency in intensive spring maize. Field Crop Res. 198:258-268.

Porto APF, Vasconcelos RC, Viana AES, Almeida MRS (2011) Variedades de milho a diferentes espaçamentos no Planalto de Vitória da Conquista - BA. Rev Bras Cienc Agra. 6:208214.

Reynaldo EF, Machado TM, Taubinger L, Quadros D (2016) Influência da velocidade de deslocamento na distribuição de sementes e produtividade de soja. Eng na Agr. 24:63-67.
Sangoi L, Almeida ML, Gracietti MA, Bianchet P (2002) Sustentabilidade do colmo em híbridos de milho de diferentes épocas de cultivo em função da densidade de plantas. Rev Cienc Agroveterinárias. 1:60-66.

Sangoi L, Schmitt A, Vieira J, Picoli Júnior GJ, Souza CA, Casa RT, Schenatto DE, Giordani W, Boniatti CM, Machado GC, Horn D (2012) Variabilidade na distribuição espacial de plantas na linha e rendimento de grãos de milho. Rev Bras milho sorgo. 11:268-277.

Sangoi L, Schweitzer C, Silva PRF, Schmitt A, Vargas VP, Casa RT, Souza C (2011) Perfilhamento, área foliar e produtividade do milho sob diferentes arranjos espaciais. Pesqui Agropecu Bras. 46:609-616.

Silva JG, Kluthcouski J, Silveira PM (2000) Desempenho de uma semeadora-adubadora no estabelecimento e na produtividade da cultura do milho sob plantio direto. Sci Agric. 57:7-12.

Silva MC, Gamero CA (2010) Qualidade da operação de semeadura de uma semeadora-adubadora de plantio direto em função do tipo de martelete e velocidade de deslocamento. Rev Energ Agr. 25:85-102.

Storck L, Modolo AJ, Brum B, Trogello E, Franchin MF, Adami PF (2015) Medida de regularidade do espaçamento de plantas de milho em diferentes sistemas de manejo. Rev Bras Eng Agr Amb. 19:39-44.

Takasu AT, Rodrigues RAF, Goes RJ, Haga K, Iwamoto OA, Gitti DC (2014) Características agronômicas da cultura do milho em função do preparo de solo e arranjo espacial de plantas. Rev Agrarian. 7:485-495.

Trogello E, Modolo AJ, Dallacort R, Baesso MM, Scarsi M (2014) Desenvolvimento do milho sobre diferentes manejos de palhada, sulcadores e velocidades de semeadura. Rev Bras Milho Sorgo. 13:142-153. 